\author{
Andrian Dolfriandra Huruta ${ }^{1}$ \\ Hans Hananto Andreas ${ }^{2}$ \\ Roberto Louis Forestal ${ }^{3}$ \\ Anboli Elangovan ${ }^{4}$ \\ John Francis Diaz
}

JEL: F3, G2

DOI:10.5937/industrija49-30692

UDC: leave blank

Original Scientific Paper

\title{
Revisiting Spillover Effect: An empirical evidence from GARCH-ARMA approach
}

\author{
Article history: \\ Received: 3 February 2021 \\ Sent for revision: 16 March 2021 \\ Received in revised form: 30 March 2021 \\ Accepted: 7 April 2021 \\ Available online: 30 April 2021
}

Abstract: This study analyzes the spillover effect of markets' commodity, exchange rate, and stock price. Starting from July 1, 2009, the daily data to December 31, 2019, are conducted in our study. The GARCH-ARMA approach has been undertaken in this study. The results show that four pairs experience the unidirectional (positive) spillover effect of return. Yet, the spillover effect of volatility shows a two-way relationship (both positive and negative) between commodity markets, stock prices, and exchange rates. To conclude, both stock prices and gold are volatility's net transmitters to other markets, while the EURUSD market is some markets' net receiver of volatility.

Keywords: GARCH-ARMA, S\&P 500, EUR/USD, Oil, Gold

\section{Preispitivanje efekta prelivanja: empirijski dokaz iz pristupa GARCH-ARMA}

Apstrakt: Ova studija analizira efekat prelivanja roba na tržištu, deviznog kursa i cena akcija. Počevši od 1. jula 2009. u studiji se sprovode dnevni podaci do 31. decembra 2019. godine. U ovoj studiji je korišćen GARCH-ARMA pristup. Rezultat pokazuje da četiri para doživljavaju jednosmerni (pozitivni) efekat prelivanja. Ipak, efekat prelivanja nestabilnosti pokazuje dvosmerni odnos (i

\footnotetext{
${ }^{1}$ Chung Yuan Christian University, Taiwan, g10804610@cycu.edu.tw

${ }^{2}$ Chung Yuan Christian University, Taiwan

${ }^{3}$ Chung Yuan Christian University, Taiwan

${ }^{4}$ Chung Yuan Christian University, Taiwan

${ }^{5}$ Asian Institute of Management, Philippines
} 
pozitivan i negativan) između robnih tržišta, cena akcija i deviznih kurseva. Da zaključimo, i cene akcija i zlato su neto prenosnici nestabilnosti na druga tržišta, dok je tržište EUR-USD neto primalac nestabilnosti na nekim tržištima.

KIjučne reči: GARCH-ARMA, S\&P 500, EUR/USD, nafta, zlato.

\section{Introduction}

Financial market instruments have seen exponential progress in recent decades, including updated technology, credit, equity growth, and other innovations. However, those changes occurred with the riskiness and volatility of major financial markets. Commodity markets, such as crude oil, had undergone strong liquidity growth and attracted many investors (Vivian and Wohar, 2012). As raw material and related energy source, oil accounts for a significant portion of the world's primary energy consumption. It shows a price increase annually at an average of $53.9 \%$ for the last ten years. One of the most well-known precious metals that have long been recognized as a secure and stable investment against hard times and unpredictable markets is gold. Over the last decade, there was a steady increase in the gold market (Narayan and Narayan 2010). From 2002-2008, an $18.5 \%$ annual growth rate was observed on the gold price.

Moreover, financial markets are increasingly embraced by the globalization trend. The expected returns are determined by both stock prices and exchange rates from a foreign investors' perspective. As a result, relationships among exchange rates, oil, gold, and stock prices become an essential topic in portfolio management. In the presence of commodity markets' financialization, foreign exchange, gold, oil, and stock prices have obtained properties of diversification. They have been correlated with each other and the global business cycle outlook (Mikhaylov, 2018). According to Drachal (2018), a specific change in the stock index price due to changes in the exchange rate.

Both of these asset price movements are important indicators of share prices. Also, understanding return and volatility transmission mechanisms among those instruments in the financial markets was is necessary for both researchers and investors. The GARCH method was used previously to find volatility spillover between crucial stock markets (e.g., financial and oil markets (Cevik et al., 2020; Contuk et al., 2013; Gokmenoglu \& Fazlollahi, 2015; Morema \& Bonga-Bonga, 2018). The interdependence of oil, gold, the USD, and stocks are identified by Samanta and Zadeh (2012). They show the possibility of more considerable spillover for a more extended period. Besides, the volatility dynamics among stock prices, wheat, oil, and copper have already 
been investigated by Sadorsky (2014). He showed stock and oil prices exhibit leverage effects.

The effect of oil on the financial volatility of G7 countries has already been analyzed by Bastianin et al. (2016). They discovered that stock market volatility does not react to changes in oil supply. The authors advised policymakers to implement and organize practical steps to maintain economic growth promptly and to stabilize stock market volatility. The interdependence among stock prices, oil, gold, and the USD are investigated by Arfaoui and Rejeb (2017). They proved the negative linkage between oil and stock prices. However, the authors demonstrated that gold and USD impact the oil price both significantly and positively.

The dynamics causality among oil, stock, and exchange rate in Central East European countries has already been investigated by Drachal (2018). He stated that oil prices negatively affect the exchange rate, and the equity market affects the exchange rate. He et al. (2020) proved gold has a positive and negative spillover in both the USA and China's stock market, respectively. Malik and Hammoudeh (2007) confirmed volatility and spillover studies have an excellent effect on asset pricing, portfolio managers, oil price, and equity.

Our study was motivated by the implications of current fluctuations in asset and commodity prices in the financial markets. Therefore, understanding this phenomenon is of great importance for portfolio managers and decisionmakers. Concerning motivation, our analysis contributes to several kinds of literature. First, we relate to the existing research studying the spillover effect among commodities, stock markets, and FOREX. Second, we show evidence corroborates Cevik et al. (2020) and prior financial theories. This study is arranged in several sections. The previous studies and hypotheses are discussed in section 2 . We provide methodology in section 3 . The empirical results and discussion are provided in section 4 . Finally, we give the conclusion section.

\section{Literature Review \& Hypotheses Development}

Previous research on the spillover effect among commodity market, stock price, and exchange rate can be found in this section. Gokmenoglu and Fazlollahi (2015) proved the long-run relationship between gold and oil on the S\&P500 stock market. Oil prices have significant effects on the stock market, as seen in Cevik et al. (2020). Besides, Ji et al. (2018) showed a considerable risk of spillover from oil to stock returns. Bouri (2015) also revealed the entire period exposes low unidirectional transmissions of return and volatilities from oil to the 
stock market. He et al. (2020) found the greatest return spillovers between the oil and stock market. Crude oil has a negative spillover return to the stock market, while the stock market has a positive spillover return.

The interdependence among oil, gold, USD, and stock price have already been identified by Arfaoui and Rejeb (2017). They found a negative linkage between oil and stock prices. Bastianin et al. (2016) found that volatility in the stock market is unrelated to oil production. However, fluctuations in oil demand have a significant effect on the stock market. Besides, Sadorsky (2014) revealed stock prices and oil prices exhibit leverage effects.

The linkage between gold on the stock exchange has been investigated by Contuk et al. (2013). They found that traditional shocks affected gold and commodity markets. Kumar (2014) showed a significant unidirectional return spillover from gold to stock sectors in a similar vein. A study by Samanta and Zadeh (2012) also found a relationship between gold and exchange rate. Antonakakis and Kizys (2015) indicated gold, silver, platinum, and exchange rates improve the spillover effect's predictive performance on returns and volatility.

Gokmenoglu and Fazlollahi (2015) found the oil market triggers the gold price changes. Arfaoui and Rejeb (2017) also demonstrated that gold and USD affect both significant and positive oil prices. Yet, Samanta and Zadeh (2012) found oil and gold have an asymmetric relationship. Morema and Bonga-Bonga (2018) showed returns in the industrial sector are more affected by oil prices. Based on these findings, the following hypotheses suggested:

$\mathrm{H} 1$ : The spillover effect of return and volatility of oil and stock price is met

$\mathrm{H} 2$ : The spillover effect of return and volatility of gold and exchange rate is met

H3: The spillover effect of return and volatility of oil and gold is met

Drachal (2018) found that oil price has a negative impact on exchange rates. Similarly, Arfaoui and Rejeb (2017) revealed that gold and USD positively impact the oil price. Besides, Samanta and Zadeh (2012) proved an asymmetric relationship between oil and the exchange rate. Katusiime (2019) revealed the impact of oil on the exchange rate.

Samanta and Zadeh (2012) found the S\&P 500 and gold have an asymmetric relationship. A related study from Arfaoui and Rejeb (2017) revealed that oil, USD, and stock markets make influence on gold. Mikhaylov (2018) also demonstrated the bidirectional spillover and effect between the stock and foreign exchange markets. A different perspective from Arfaoui and Rejeb (2017) found the exchange rate has a negative impact on the stock market. Besides, Samanta and Zadeh (2012) showed an asymmetric relationship 
between the stock price and the exchange rate. According to these findings, the following hypotheses suggested:

$\mathrm{H} 4$ : The spillover effect of return and volatility between oil and exchange rate are met

H5: The spillover effect of return and volatility between the stock price and gold are met

H6: The spillover effect of return and volatility between stock price and exchange rate are met

\section{Methodology}

This study using daily data from 2009/07/01 - 2019/12/31 of commodity markets (gold and oil), exchange rate (EUR/USD), and stock prices (S\&P 500). The daily closing prices for stock commodities (ETF), the exchange rate (forex), and stock price collected from Yahoo Finance. The regular returns have been assessed as changing the natural log of the following days' closing prices. The GARCH-ARMA was performed to explain both conditional heteroscedasticities of data and GARCH effects between gold, oil, EUR/USD, and the S\&P 500. Simultaneously, the GARCH-ARMA model was performed to evaluate the spillover effect (Chen \& Huang, 2010).

The ETF returns model (GARCH-ARMA)

$$
\begin{aligned}
& R_{i, t}^{e}=\alpha_{0}+\sum_{i=1}^{g} \alpha_{i} R_{i, t-i}^{e}+\varepsilon_{i, t}^{e}+\sum_{i=1}^{s} \theta_{i} \varepsilon_{i, t-i}^{e} \\
& h_{i, t}^{e}=a_{0}+\sum_{i=1}^{q} a_{i} \varepsilon_{i, t-1}^{e^{2}}+\sum_{i=1}^{p} \psi_{i} h_{i, t-i}^{e}
\end{aligned}
$$

$$
\begin{array}{ll}
R_{i, t}^{e} & : \text { ETF returns at } t \text { period } \\
\sum_{\substack{i=1 \\
\varepsilon_{i, t}^{e}}}^{e} \alpha_{i} R_{i, t-i}^{e} & : \text { Higher-order for return of autoregressive A.R. (g) } \\
& : \text { Error term of ETF at } t \text { period }
\end{array}
$$




$$
\begin{array}{ll}
\sum_{i=1}^{\varepsilon_{i, t}^{e}} \theta_{i} \varepsilon_{i, t-i}^{e} & : \text { Higher-order Moving Average MA(s) shows } R_{i, t}^{e} \text { process } \\
\sum_{i=1}^{p} \psi_{i} h_{i, t-i}^{e} & : \begin{array}{l}
\text { Conditional heteroscedasticity (p order) of GARCH for ETF } \\
q
\end{array} \\
\sum_{i=1}^{q} a_{i} \varepsilon_{i, t-1}^{e^{2}} & : \text { period } \\
& \text { ARCH (q order) for ETF at } t-1 \text { period }
\end{array}
$$

The stock index returns model (GARCH- ARMA)

$$
\begin{aligned}
& R_{i, t}^{m}=\beta_{0}+\sum_{i=1}^{g} \beta_{i} R_{i, t-i}^{m}+\varepsilon_{i, t}^{m}+\sum_{i=1}^{s} \gamma_{i} \varepsilon_{i, t-i}^{m} \\
& h_{i, t}^{m}=b_{0}+\sum_{i=1}^{q} b_{i} \varepsilon_{i, t-i}^{m^{2}}+\varepsilon_{i, t}^{m}+\sum_{i=1}^{p} \xi_{i} h_{i, t-i}^{m}
\end{aligned}
$$

$R_{i, t}^{m}:$ The $\mathrm{i}^{\text {th }}$ stock index returns at $t$ period

$\varepsilon_{i, t}^{m}:$ The $\mathrm{i}^{\text {th }}$ stock index returns residual at $t$ period

$h_{i, t}^{m}:$ The $\mathrm{i}^{\text {th }}$ conditional variance of stock index returns at $t$ period

$\gamma_{i}:$ Unknown parameter

The spillover effect of returns

$$
\begin{gathered}
R_{i, t}^{e}=\alpha_{0}+\sum_{i=1}^{g} \alpha_{i} R_{i, t-i}^{e}+w R_{i, t-1}^{e}+\varepsilon_{i, t}^{e} \\
+\sum_{i=1}^{s} \theta_{i} \varepsilon_{i, t-i}^{e} \\
h_{i, t}^{e}=a_{0}+\sum_{i=1}^{q} a_{i} \varepsilon_{i, t-i}^{e^{2}}+\sum_{i=1}^{p} \psi_{i} h_{i, t-i}^{e}
\end{gathered}
$$




$$
\begin{aligned}
R_{i, t}^{m}=\beta_{0}+ & \sum_{i=1}^{g} \beta_{i} R_{i, t-i}^{m}+d R_{i, t-1}^{e}+\varepsilon_{i, t}^{m} \\
& +\sum_{i=1}^{s} \gamma_{i} \varepsilon_{i, t-i}^{m} \\
h_{i, t}^{m}= & b_{0}+\sum_{i=1}^{q} b_{i} \varepsilon_{i, t-1}^{m^{2}}+\sum_{i=1}^{p} \xi_{i} h_{i, t-i}^{m}
\end{aligned}
$$

Our model tests $\mathrm{H}_{0}(w=0 ; d=0)$ and $\mathrm{H}_{1}(w \neq 0 ; d \neq 0)$. $\mathrm{H}_{0}$ means the order does not have spillover effects of returns. In contrast, $\mathrm{H}_{1}$ means the order has a spillover effect of returns.

The spillover effect of volatilities

$$
\begin{aligned}
& R_{i, t}^{e}=\alpha_{0}+\sum_{i=1}^{g} \alpha_{i} R_{i, t-i}^{e}+\varepsilon_{i, t}^{e}+\sum_{i=1}^{s} \theta_{i} \varepsilon_{i, t-i}^{e} \\
& h_{i, t}^{e}=a_{0}+\sum_{i=1}^{q} a_{i} \varepsilon_{i, t-1}^{e^{2}}+\sum_{i=1}^{p} \psi_{i} h_{i, t-i}^{e}+v \varepsilon_{i, t-1}^{m^{2}}
\end{aligned}
$$

$$
\begin{aligned}
& R_{i, t}^{m}=\beta_{0}+\sum_{i=1}^{g} \beta_{i} R_{i, t-i}^{e}+\varepsilon_{i, t}^{m}+\sum_{i=1}^{s} \gamma_{i} \varepsilon_{i, t-i}^{m} \\
& h_{i, t}^{m}=b_{0}+\sum_{i=1}^{q} b_{i} \varepsilon_{i, t-i}^{m^{2}}+\sum_{i=1}^{p} \xi_{i} h_{i, t-i}^{m}+l \varepsilon_{i, t-1}^{e^{2}}
\end{aligned}
$$

We conduct $\mathrm{H}_{0}(v=0 ; I=0)$ and $\mathrm{H}_{1}(v \neq 0 ; I \neq 0) . \mathrm{H}_{0}$ means the order does not have a spillover effect of volatility. In contrast, the $\mathrm{H}_{1}$ reveals order has a spillover effect of volatility. 


\section{Empirical Results and Discussion}

This section provides the empirical results that were obtained in several steps. First, we run descriptive statistics in Table 1. Second, we run the unit root test (Augmented Dickey-Fuller) in Table 2. Third, we provide the Lagrange Multiplier test in Table 2. Fourth, we give the ARMA-LM test in Table 2. The last, we run the spillover effects of returns and volatilities test using GARCH-ARMA models in Table 3.

Table 1. Sample Size and summary statistics

\begin{tabular}{|c|c|c|c|c|c|c|c|}
\hline Pairs & $\begin{array}{c}\text { ETF/Stock/ } \\
\text { Forex }\end{array}$ & Obs.* & Mean & Std. Dev. & Skew. & Kurt. & J-Bera \\
\hline \multirow{2}{*}{1} & Oil & \multirow{2}{*}{2619} & $4.45 \mathrm{E}-07$ & 0.000206 & 0.098478 & 5.988155 & $\begin{array}{c}978.6177 \\
(0.000000)^{\star \star *}\end{array}$ \\
\hline & S\&P 500 & & 0.047711 & 0.936646 & -0.533207 & 7.152541 & $\begin{array}{c}2005.809 \\
(0.000000)^{\star * *}\end{array}$ \\
\hline \multirow{2}{*}{2} & Gold & \multirow{2}{*}{2610} & 0.018234 & 1.002410 & -0.711876 & 9.734351 & $\begin{array}{c}5152.418 \\
(0.000000)^{\star \star \star}\end{array}$ \\
\hline & EUR-USD & & -0.008994 & 0.584130 & -0.046638 & 4.877911 & $\begin{array}{c}384.4583 \\
(0.000000)^{\star \star *}\end{array}$ \\
\hline \multirow[b]{2}{*}{3} & Oil & \multirow{2}{*}{2618} & -0.004455 & 2.058149 & 0.097951 & 5.983447 & $\begin{array}{c}975.1325 \\
(0.000000)^{\star \star *}\end{array}$ \\
\hline & Gold & & 0.018178 & 0.999436 & -0.729706 & 9.771429 & $\begin{array}{c}5234.051 \\
(0.000000)^{\star * *}\end{array}$ \\
\hline \multirow{2}{*}{4} & Oil & \multirow{2}{*}{2617} & -0.004457 & 2.058211 & 0.098519 & 5.984241 & $\begin{array}{c}975.3250 \\
(0.000000)^{\star * *}\end{array}$ \\
\hline & EUR-USD & & -0.008970 & 0.593687 & 0.007058 & 4.960898 & $\begin{array}{c}419.3000 \\
(0.000000)^{\star \star *}\end{array}$ \\
\hline \multirow[b]{2}{*}{5} & S\&P 500 & \multirow{2}{*}{2620} & 0.047693 & 0.936706 & -0.533964 & 7.151394 & $\begin{array}{c}2005.888 \\
(0.000000)^{\star \star \star}\end{array}$ \\
\hline & Gold & & 0.018164 & 0.999211 & -0.729343 & 9.773031 & $\begin{array}{c}5240.188 \\
(0.000000)^{\star * *}\end{array}$ \\
\hline \multirow[b]{2}{*}{6} & S\&P 500 & \multirow{2}{*}{2640} & 0.047331 & 0.939589 & -0.483017 & 7.299814 & $\begin{array}{c}2136.378 \\
(0.000000)^{\star \star \star}\end{array}$ \\
\hline & EUR-USD & & -0.008892 & 0.578625 & -0.064944 & 4.891990 & $\begin{array}{c}395.6148 \\
(0.000000)^{\star \star \star}\end{array}$ \\
\hline
\end{tabular}

Note: * The samples vary slightly because we excluded some missing observations from each dataset.

*** $\mathrm{p}<0.01$

Source: Authors' calculations

Table 1 details the sample size and summary statistics of our pairs of variables. The mean value is positive in both the first pair (Oil/S\&P 500) and fifth pair (S\&P 500 /EUR-USD) of variables, while the negative number is shown all around the fourth pair (Oil/EUR-USD). A positive value is shown concomitantly with a negative one in pairs holding gold/EUR-USD, oil/gold, and S\&P 500/EUR-USD, implying that S\&P 500 and gold are more likely to return positive value on average while investing in EUR-USD is expected to yield negative return. Moreover, oil can return either positive or negative value depending on the pair and sub-sample period. The standard deviation value can be used to determine the variance. Gold and S\&P 500 returns have a standard deviation close to 1 74 
and are among the most volatile instruments. In contrast, EUR-USD returns, with a standard deviation score approximating 0.6 are the less risky investment, confirming the risk-return tradeoff principle claiming that higher risk leads to a higher return. Oil, with a standard deviation of 0.000206 in pair one, can be considered a safe investment but is more likely to be very volatile in pairs 3 and 4.

From the Jarque-Bera, all the residual normality shows all couples have normal distribution at the level significance of $1 \%$. Then, to describe the normal distribution's asymmetry, all the pairs have a negative (left skewness) positive (right skewness) value. The first pair shows there are positive (Oil) and negative skewness (S\&P 500). In the second pair of gold and EUR-USD, there is all negative skewness. The third pair shows there is a positive (Oil) and negative skewness (Gold). The fourth pair from oil and EUR-USD has positive skewness. The fifth pair of S\&P 500 and gold have negative skewness. Similarly, the last pair of S\&P 500 and EUR-USD have negative skewness. Regarding the kurtosis coefficient, all the couples have a leptokurtic distribution (positive excess kurtosis).

Table 2. Summary Statistics of Unit Root, Lagrange Multiplier, and ARMA-LM

tests

\begin{tabular}{|c|c|c|c|c|c|c|c|c|c|}
\hline Pairs & $\begin{array}{c}\text { ETF/ } \\
\text { Stock/ } \\
\text { Forex }\end{array}$ & ADF & ARMA & AIC & LM & ARCH-LM & GARCH & AIC & $\begin{array}{c}\text { ARCH- } \\
\text { LM }\end{array}$ \\
\hline \multirow[b]{2}{*}{1} & Oil & $-53.64100^{\star \star *}$ & $(2,2)$ & -14.14297 & 0.620279 & $138.1754^{\star \star *}$ & $(2,2)$ & -14.32031 & 0.413758 \\
\hline & $\begin{array}{l}\text { S\&P } \\
500\end{array}$ & $-25.36958^{\star \star *}$ & $(2,1)$ & 2.700843 & 3.955027 & $121.6691^{\star \star *}$ & $(2,1)$ & 2.415304 & 0.444948 \\
\hline \multirow{2}{*}{2} & Gold & $-52.71938^{\star * *}$ & $(2,1)$ & 2.842506 & 0.695275 & $32.21639^{* * *}$ & $(1,2)$ & 2.738057 & 4.228803 \\
\hline & $\begin{array}{l}\text { EUR- } \\
\text { USD }\end{array}$ & $-53.33327^{\star * *}$ & $(0,1)$ & 1.760668 & 2.302857 & $44.73509^{\star \star \star}$ & $(1,2)$ & 1.628034 & 0.790696 \\
\hline \multirow{2}{*}{3} & Oil & $-53.57111^{* \star *}$ & $(2,2)$ & 4.278319 & 0.612599 & $190.9350^{* * *}$ & $(2,1)$ & 4.103619 & 1.789728 \\
\hline & Gold & $-52.5589^{* \star *}$ & $(1,1)$ & 2.836666 & 1.493204 & $34.39314^{* * *}$ & $(1,2)$ & 2.730744 & 5.394733 \\
\hline \multirow{2}{*}{4} & Oil & $-53.52875^{\star \star *}$ & $(0,1)$ & 4.278445 & 3.976900 & $190.2531^{* * *}$ & $(2,1)$ & 4.100929 & 1.970369 \\
\hline & $\begin{array}{l}\text { EUR- } \\
\text { USD }\end{array}$ & $-53.52758^{\star \star \star}$ & $(0,1)$ & 1.792982 & 3.125441 & $37.48523^{\star \star \star}$ & $(1,2)$ & 1.662596 & 0.361846 \\
\hline \multirow{2}{*}{5} & $\begin{array}{l}\text { S\&P } \\
500\end{array}$ & $-25.50195^{\star * *}$ & $(2,2)$ & 2.695887 & 1.745766 & $362.6613^{* * *}$ & $(2,1)$ & 2.413817 & 0.281104 \\
\hline & Gold & $-52.61368^{\star \star *}$ & $(1,1)$ & 2.836178 & 1.474467 & $34.36977^{\star \star \star}$ & $(1,2)$ & 2.730178 & 5.41675 \\
\hline \multirow{2}{*}{6} & $\begin{array}{l}\text { S\&P } \\
500\end{array}$ & $-25.43514^{\star \star *}$ & $(2,2)$ & 2.702474 & 1.234730 & $375.8176^{\star \star *}$ & $(2,1)$ & 2.41312 & 0.484678 \\
\hline & $\begin{array}{l}\text { EUR- } \\
\text { USD }\end{array}$ & $-53.67966^{\star \star *}$ & $(2,2)$ & 1.743379 & 2.705335 & $44.67231^{\star \star *}$ & $(1,2)$ & 1.608645 & 0.841415 \\
\hline
\end{tabular}


Table 2 demonstrates the Augmented Dickey-Fuller test to examine the stationarity of our instruments' returns and the minimum value of the Akaike Information Criterion to identify the models' orders. The resulting ADF unit-root test results revealed that the alternative of no unit roots accepted for both stock index and Forex returns, which supported the stationary of the time-series data. The Breusch-Godfrey Lagrange Multiplier (L.M.) test was applied, and it contributed to no serial correlation in all pairs samples. Then, we turned to GARCH- ARMA models' model diagnostics based on the Akaike information criterion's minimum value (AIC). We used the Lagrange Multiplier test (ARCH$\mathrm{LM}$ ) to test the ARCH effect and eliminate heteroscedasticity in the data's volatility. Comparing the ARMA model's relevant statistics, we rejected the null hypothesis of no ARCH effect and significantly accepted the ARCH effect's alternative explanation for all samples. Thus, the test results suggest no autoregressive conditional heteroscedasticity for each sub-sample in the GARCH-ARMA models.

Table 3. Spillover effects of returns and volatilities

\begin{tabular}{|c|c|c|c|c|c|}
\hline \multirow{2}{*}{ Pairs } & \multirow{2}{*}{ ETF/Stock/Forex } & \multicolumn{2}{|c|}{ Spillover Effect of Returns } & \multicolumn{2}{|c|}{ Spillover Effect of Volatility } \\
\hline & & Oil & S\&P 500 & Oil & S\&P 500 \\
\hline 1 & Oil/S\&P 500 & $\begin{array}{c}\text { 7.74E-06 } \\
(0.0375)^{\star *}\end{array}$ & $\begin{array}{c}-22.34484 \\
(0.7657)\end{array}$ & $\begin{array}{c}-0.460021 \\
(0.0559)^{*}\end{array}$ & $\begin{array}{l}-0.517838 \\
(0.0000)^{* * *}\end{array}$ \\
\hline \multirow{2}{*}{ Pairs } & \multirow{2}{*}{ ETF/Stock/Forex } & \multicolumn{2}{|c|}{ Spillover Effect of returns } & \multicolumn{2}{|c|}{ Spillover Effect of Volatility } \\
\hline & & Gold & EUR-USD & Gold & EUR-USD \\
\hline 2 & Gold/EUR-USD & $\begin{array}{l}0.022910 \\
(0.4821)\end{array}$ & $\begin{array}{c}0.139040 \\
(0.0000)^{\star \star *}\end{array}$ & $\begin{array}{l}-0.530602 \\
(0.0004)^{\star * *}\end{array}$ & $\begin{array}{l}-0.461113 \\
(0.0000)^{* *}\end{array}$ \\
\hline \multirow{2}{*}{ Pairs } & \multirow{2}{*}{ ETF/Stock/Forex } & \multicolumn{2}{|c|}{ Spillover Effect of Returns } & \multicolumn{2}{|c|}{ Spillover Effect of Volatility } \\
\hline & & Oil & Gold & Oil & Gold \\
\hline 3 & Oil/Gold & $\begin{array}{l}0.010105 \\
(0.7798)\end{array}$ & $\begin{array}{c}0.001772 \\
(0.214709)\end{array}$ & $\begin{array}{c}-0.876841 \\
(0.0000)^{* * *}\end{array}$ & $\begin{array}{c}-1.218864 \\
(0.0000)^{\star * *}\end{array}$ \\
\hline \multirow{2}{*}{ Pairs } & \multirow{2}{*}{ ETF/Stock/Forex } & \multicolumn{2}{|c|}{ Spillover Effect of Returns } & \multicolumn{2}{|c|}{ Spillover Effect of Volatility } \\
\hline & & Oil & EUR-USD & Oil & EUR-USD \\
\hline 4 & Oil/EUR-USD & $\begin{array}{l}0.076541 \\
(0.1703)\end{array}$ & $\begin{array}{c}0.023484 \\
(0.0000)^{\star * *}\end{array}$ & $\begin{array}{l}-1.190518 \\
(0.0000)^{\star * *}\end{array}$ & $\begin{array}{c}-0.778874 \\
(0.0000)^{\star * *}\end{array}$ \\
\hline \multirow{2}{*}{ Pairs } & \multirow{2}{*}{ ETF/Stock/Forex } & \multicolumn{2}{|c|}{ Spillover Effect of Returns } & \multicolumn{2}{|c|}{ Spillover Effect of Volatility } \\
\hline & & S\&P 500 & Gold & S\&P 500 & Gold \\
\hline 5 & S\&P 500/Gold & $\begin{array}{c}-0.000282 \\
(0.9845)\end{array}$ & $\begin{array}{l}0.010597 \\
(0.5450)\end{array}$ & $\begin{array}{c}0.791407 \\
(0.0000)^{* * *}\end{array}$ & $\begin{array}{c}-2.080750 \\
(0.0007)^{\star * *}\end{array}$ \\
\hline \multirow{2}{*}{ Pairs } & \multirow{2}{*}{ ETF/Stock/Forex } & \multicolumn{2}{|c|}{ Spillover Effect of Returns } & \multicolumn{2}{|c|}{ Spillover Effect of Volatility } \\
\hline & & S\&P 500 & EURO-USD & S\&P 500 & EUR-USD \\
\hline 6 & $\begin{array}{c}\text { S\&P } 500 / E U R- \\
\text { USD }\end{array}$ & $\begin{array}{c}0.017778 \\
(0.4805)\end{array}$ & $\begin{array}{c}0.070066 \\
(0.0000)^{\star * \star}\end{array}$ & $\begin{array}{c}0.663813 \\
(0.0000)^{\star * *}\end{array}$ & $\begin{array}{c}-0.453535 \\
(0.0000)^{\star * *}\end{array}$ \\
\hline
\end{tabular}

Note: ${ }^{*} p<0.1$

** $p<0.05$

${ }^{* * *} p<0.01$

76

Industrija, Vol.49, No.1, 2021 
Table 3 reveals the spillover effects of returns have two patterns: the first pattern (first pair, second pair, fourth pair, and sixth pair) and the second pattern (third and fifth pair). In the first pair, there is a unidirectional spillover effect on the return of each pair. The S\&P 500 generates more minor but positive spillover on oil, while oil's return affect on S\&P 500 is statistically insignificant. These findings are significant at the level of significance of $1 \%$ and $5 \%$. Moreover, results show that EUR-USD has no substantial spillover effect on any other instrument, including gold, oil, and S\&P 500 but appears to be positively affected by gold (0.139040), oil (0.023484), and S\&P $500(0.070066)$, suggesting that EUR-USD is a net receiver of returns from other markets. This unidirectional relationship implies that the oil sector's performances, one of the critical commodity markets, are affected by the S\&P 500 equity stock marketspecific information flow. These effects support Arfaoui and Rejeb's (2017) recent findings and Antonakakis and Kizys (2015). One possible explanation of those findings is that the worldwide demand on the oil commodity market is linked to corporate risk rating. The corporate default premium has a particular effect on the international oil price. Cevik et al. (2020) argued that oil prices had become progressively correlated with the futures price of the non-energy sector due to the financialization process.

Also, we showed both gold and oil have a positive and significant spillover effect on EUR-USD returns. In contrast, EUR-USD return shows no considerable spillover effect on either gold or oil returns. Overall, the findings suggest that the return spillover index divides the variables into two groups according to whether they are net transmitters or net receivers of spillovers. The clear signals of volatilities include S\&P 500 and gold, while the net receiver is EURUSD. Those findings, in line with studies such as He et al. (2020), confirm the safe-haven investment status of gold because the return spillover effect of other instruments on gold insignificant, while its spillover effect on others is quite significant.

Further, the first until the sixth pair (Oil/S\&P 500, Gold/EUR-USD, Oil/Gold, Oil/EUR-USD, S\&P 500/Gold, and S\&P 500/EUR-USD) the bidirectional spillover effect of volatility. These findings are based on the probability value, which is significant at the significance level of $1 \%$ and $10 \%$. Interestingly, we have two patterns, as shown by the first pattern (first pair until the fourth pair) and the second pair (fifth pair until the sixth pair). The first pattern shows that there is a negative relationship between each pair. While the second pattern shows, there is a different pattern between each pair. The S\&P 500 index spills $-46.00 \%$ to the oil market and $-45.35 \%$ to the EUR-USD market. 
Finally, the volatility transmissions from the gold market to EUR-USD, oil, and S\&P 500 are $-46.11 \%,-87.7 \%$, and $79.14 \%$, respectively. While gold has adverse effects on the EUR-USD and oil volatility, it positively impacts. Furthermore, the S\&P 500 and the gold are the net transmitters of volatility to other markets, whereas the EUR-USD market is the net receiver of volatility from other markets. Overall, we can say that gold is a haven for portfolio investors during the entire observation period because the volatility spillover to the gold market is relatively small, and it is a net volatility transmitter rather than a receiver.

\section{Conclusions}

Concentrated on regular data from July 1,2009 , to December 31,2019 , this analysis explores the spillover effect of returns and volatilities. We find the stock price has a positive and unidirectional spillover effect on oil return. In a similar vein, gold has the same direction on EUR/USD return. Oil has the same direction on EUR/USD return. Besides, the stock price has the same direction on oil return. However, six pairs experience the bidirectional (both positive and negative) spillover effect of volatility.

We can conclude the net transmitters of volatility to other markets are stock price and gold based on our findings. However, the net receiver of volatility from another market is the EUR-USD market. Also, we prove gold is the safe-haven for portfolio investors during the observation period since the volatility spillover to the gold market is relatively small and is not a receiver but a net volatility transmitter. Finally, the spillover effect of returns and volatility between commodity markets, exchange rates, and stock price continues to be essential for investors to buy or sell strategies that they may account for directly. As such, it will help investors to make better investment decisions.

Our study only concerns the spillover effect of returns and volatility among gold, oil, exchange rate, and S\&P 500. Hence we suggest future studies to analyze the spillover effect in a particular region, such as ASEAN+3 countries, ASEAN+6 countries, BRICS countries, EMU countries, OECD countries, etc. Moreover, future studies need to consider the global financial crisis and Coronavirus pandemic data period. We also leave for future research to use various formal statistical analyses to confirm the results further, such as models of E-GARCH, AFRIMA, etc. 


\section{References}

Antonakakis, N., \& Kizys, R. (2015). Dynamic spillovers between commodity and currency markets. International Review of Financial Analysis, 41, 303-319. https://doi.org/10.1016/j.irfa.2015.01.016

Arfaoui, M., \& Rejeb, A. B. (2017). Oil, gold, U.S. dollar and stock market interdependencies: a global analytical insight. European Journal of Management and Business Economics, 26(3), 278-293. https://doi.org/10.1108/EJMBE-102017-016

Bastianin, A., Conti, F., \& Manera, M. (2016). The impacts of oil price shocks on stock market volatility: Evidence from the G7 countries. Energy Policy, 98, 160-169. https://doi.org/10.1016/j.enpol.2016.08.020

Bouri, E. (2015). Return and volatility linkages between oil prices and the Lebanese stock market in crisis periods. Energy, $X X X, 1-7$. https://doi.org/10.1016/j.energy.2015.05.121

Cevik, N. K., Cevik, E. I., \& Dibooglu, S. (2020). Oil prices, stock market returns and volatility spillovers: Evidence from Turkey. Journal of Policy Modeling, In press, 1-24. https://doi.org/10.1016/j.jpolmod.2020.01.006

Chen, J.-H., \& Huang, C.-Y. (2010). An analysis of the spillover effects of exchangetraded funds. Applied Economics, 42(9), 1155-1168. https://doi.org/10.1080/00036840701721182

Contuk, F. Y., Burucu, H., \& Güngör, B. (2013). Oil Prices, Stock Market Returns and Volatility Spillovers: Evidence from Turkey. International Journal of Economics and Finance Studies, 5(1), 119-140.

Drachal, K. (2018). Exchange rate and oil price interactions in selected CEE countries. Economies, 6(2), 1-21. https://doi.org/10.3390/economies6020031

Gokmenoglu, K. K., \& Fazlollahi, N. (2015). The Interactions among Gold, Oil, and Stock Market: Evidence from S\&P500. Procedia Economics and Finance, 25, 478-488. https://doi.org/10.1016/s2212-5671(15)00760-1

He, X., Takiguchi, T., Nakajima, T., \& Hamori, S. (2020). Spillover effects between energies, gold, and stock: the United States versus China. Energy and Environment, O(0), 1-32. https://doi.org/10.1177/0958305X20907081

Ji, Q., Liu, B. Y., Zhao, W. L., \& Fan, Y. (2018). Modelling dynamic dependence and risk spillover between all oil price shocks and stock market returns in the BRICS. International Review of Financial Analysis, 1-35. https://doi.org/10.1016/j.irfa.2018.08.002

Katusiime, L. (2019). Investigating spillover effects between foreign exchange rate volatility and commodity price volatility in Uganda. Economies, 7(1), 1-17. https://doi.org/10.3390/economies7010001

Kumar, D. (2014). Return and volatility transmission between gold and stock sectors: Application of portfolio management and hedging effectiveness. IIMB Management Review, 26(1), 5-16. https://doi.org/10.1016/j.iimb.2013.12.002

Malik, F., \& Hammoudeh, S. (2007). Shock and volatility transmission in the oil, U.S. and Gulf equity markets. International Review of Economics and Finance, 16(3), 357-368. https://doi.org/10.1016/j.iref.2005.05.005

Industrija, Vol.49, No.1, 2021 
Mikhaylov, A. Y. (2018). Volatility spillover effect between stock and exchange rate in oil exporting countries. International Journal of Energy Economics and Policy, 8(3), $321-326$.

Morema, K., \& Bonga-Bonga, L. (2018). The impact of oil and gold price fluctuations on the South African equity market: volatility spillovers and implications for portfolio management. In Munich Personal RePec Archive (Issue 87637). https://doi.org/10.1227/01.NEU.0000349921.14519.2A

Narayan, P. K., \& Narayan, S. (2010). Modelling the impact of oil prices on Vietnam's stock prices. Applied Energy, 87(1), 356-361. https://doi.org/10.1016/j.apenergy.2009.05.037

Sadorsky, P. (2014). Modeling volatility and correlations between emerging market stock prices and the prices of copper, oil and wheat. Energy Economics, 43, 72 81. https://doi.org/10.1016/j.eneco.2014.02.014

Samanta, S. K., \& Zadeh, A. H. M. (2012). Co-movements of Oil, Gold, the U.S. Dollar, and Stocks. Modern Economy, 3, 111-117. https://doi.org/10.4236/me.2012.31015

Vivian, A., \& Wohar, M. E. (2012). Commodity volatility breaks. Journal of International Financial Markets, Institutions and Money, 22(2), 395-422. https://doi.org/10.1016/j.intfin.2011.12.003 